\title{
High-tech industrial development vs. climate change of the Sonora-Baja California region of Mexico
}

\section{Gustavo López Badilla ${ }^{1}$, María Marcela Acosta Gomez ${ }^{2}$, Elizabeth Romero Samaniego 3 , Sandra Luz Toledo Perea ${ }^{3}$}

${ }^{1}$ IResearcher-Academic, Basic Sciences Deparment, Instituto Tecnológico de Mexicali, Mexicali, B.C., Mexico

${ }^{2}$ IResearcher-Academic, Chemical Deparment, Instituto Tecnológico de Mexicali, Mexicali, B.C., Mexico

${ }^{3}$ IResearcher-Academic, Indusrial Engineering Deparment, Instituto Tecnológico de Ensenada, Ensenada, B.C., Mexico

\section{Email address:}

glopezbadilla@yahoo.com(G. L. Badilla)

\section{To cite this article:}

Gustavo López Badilla, María Marcela Acosta Gomez, Elizabeth Romero Samaniego, Sandra Luz Toledo Perea. High-Tech Industrial Development VS. Climate Change of the Sonora-Baja California Region of Mexico. American Journal of Chemical Engineering. Vol. 1, No. 1, 2013, pp. 11-16. doi: 10.11648/j.ajche.20130101.13

\begin{abstract}
The industrialization of cities has generated considerable technological developments, with modern communication systems, specialized machinery and automated electronic systems. Large cities in Mexico, including Mexico City, Guadalajara, Monterrey and Tijuana, as well as others that have grown enormously, were including the cities of the border areas with the U.S., the central and southern part of the country. High technology developed is considered better to the economic and educational growth, but causing damage to the environment due to lack of the environmental control. This has led to the generation of variations in climatic factors, especially humidity, temperature and solar radiation, contributing to the climate change. A study conducted in the northwest of Mexico in the states of Sonora (Agua Prieta, Ciudad Obregon, Hermosillo, Nogales and San Luis Rio Colorado cities) and Baja California (Ensenada, Mexicali and Tijuana cities), where has noted that in the past 20 years, have increased the number of companies, determined by the industrial plant organizations. This research was made in the years of 2007 to 2009 . In this study we show analysis of environmental degradation, influenced by a portion of emissions to water, air and soil of companies and around of it. Another important factor is that the industrialized city population tends to grow which causes an increase in emissions of $\mathrm{CO}$ and $\mathrm{NO}_{\mathrm{X}}$ from motor vehicles, solid and water waste of domestic, industrial and commercial activities. This generates a large pollution in certain periods of the year, mostly in the winter time when emissions are concentrated to only a few meters above the ground. Increases of deterioration of the environment near of companies were correlated with the industries established in the mentioned cities from 1990 to 2010 (with statistical analysis trend at year end). This was made measuring the increase concentration of major air pollutants with equipment and specialized measurement techniques, and also was monitoring the humidity and temperature variations and $\mathrm{pH}$ analysis characterization in water and soil near of the industrial plants, to know about the acidity levels.
\end{abstract}

Keywords: High Technology, Industrialization, Climate Change, Pollution

\section{Introduction}

The modernization of large and small cities has contributed to the climate change and natural disasters generated by a destabilization of society, that sometimes causes great human and economic tragedies. When people know that they can survive, in only hours or minutes, their houses and other things obtained by several years of work activities, it very quickly disappears without leaving anything of it [1]. This has contributed to the creation of environments that impact in the water quality, air and soil, due to the implementation of commercial, industrial and domestic, in an unbalanced ways without a proper environmental care. This has led to the climate change that can originates drastic changes in the weather characteristics and generates high risks to communities by the presence of heavy rains and drought principally, affecting drastically to the populations [2]. This causes health problems arise from malnutrition in society, development and proliferation of respiratory and gastrointestinal diseases, due to the low productivity of crops [3]. Another important factor is the 
disappearance of some species of plants that produce oxygen $\left(\mathrm{O}_{2}\right.$, vital to humans), animals that break the food water, air and soil [4]. For some seismic zones, as in the Mexicali city, the climate change, can originate some earthquakes, as the occurred of 7.2 on the Richter scale in April 2010, which caused a disaster. The events that are presented in this tragedy, some human losses, injuries and damage to agricultural zones, generating large economic costs and a destabilization of society, who live with a panic waiting have a reoccurrence again and decrease of its economy. The drastic changes in outdoor and indoor of industrial plants have a large negative effect on the health of people that work in these places, with the exposition to air pollutants that exceed the standards of air quality. Also the deterioration of materials causes large unnecessary expenses, reducing. industrial economy and affecting to people because sometimes these companies debit close and populations thus the not have work decreasing their economy. This originates a social imbalance and the presence of vandalism, causing society problems, as insecurity and mainly a large decrease in the social factors [6]. This is part of an unwanted sustainable development, being an important factor that will continue on its way to an uncertain future for new generations to leave and could lead to a breakdown of society and the origin of new diseases, and economic losses, being an uncontrollable social problem.

\subsection{Evaluation of the Increase in Companies in Arid, Semi-Arid and Marine.}

The increase in the industrial plants is an important factor in the economy of each region, being a good resource to provide development opportunities to the people of the country. The main branches of industrial plants in the northwest of Mexico are the electronics, medical and metal and mechanical activities [7]. Government institutions that postulate and are care the environmental standards, in each region of the world, mention that the industrial plants debit have competitive operations in the field of investment, taking into account the security and social peace in each zone. This leads to the development of new technologies in the country, which were previously developed in the countries of origin of the industries and were subsequently implemented in different regions of Mexico. At the same time, it helps to be a country with highly qualified and competitive with other countries. According to the industry associations in each region evaluated in this study, the number of plants installed in the cities mentioned above, have a bit rate varies, being in Agua Prieta, Nogales, Mexicali and Tijuana, which exceeded the 100 companies since 1990 and the other cities with less of industrial plants than $100[8,9]$. Below average observed in the number of industrial plants in each city as well as a ratio of increase from 1990 to 2010 (with data through September and October trend of each year).

Table 1. Perceptual increase of industrial plants in Sonora and Baja California (1990-2010*)

\begin{tabular}{|c|c|c|c|c|c|c|}
\hline \multirow{2}{*}{$\begin{array}{c}\text { STATE } \\
\text { CITY }\end{array}$} & \multirow{2}{*}{ AMAQ } & \multirow{2}{*}{ CAN } & \multicolumn{3}{|c|}{ INDUSTRIAL PLANTS } & \multirow{2}{*}{$\begin{array}{c}\text { INCREASE } \\
(\%)\end{array}$} \\
\hline & & & 1990 & 2000 & 2010* & \\
\hline \multicolumn{7}{|l|}{ SONORA } \\
\hline Agua Prieta (AG) & & & 60 & 87 & 109 & 45.0 \\
\hline Cd. Obregón (CO) & & & 58 & 71 & 83 & 30.1 \\
\hline Hermosillo (HER) & & & 65 & 83 & 97 & 33.0 \\
\hline Nogales (NOG) & & & 79 & 106 & 136 & 42.0 \\
\hline San Luis R.C. (SLRC) & & & 22 & 27 & 31 & 29.0 \\
\hline \multicolumn{7}{|l|}{$\overline{\text { BAJA CALIFORNIA }}$} \\
\hline Ensenada (ENS) & & & 58 & 69 & 82 & 29.3 \\
\hline Mexicali (MEX) & & & 89 & 108 & 143 & 37.8 \\
\hline Tijuana (TIJ) & & & 102 & 123 & 187 & 45.5 \\
\hline
\end{tabular}

*Tendency to December 2010. / AMAQ. ASOCIACION DE MAQUILADORAS CAN. CANACINTRA, that are government dependences which have register of the quantity of companies in each city of Mexico

The table 1 shows the percentage increases for each city companies evaluated, showing that the higher states was in Tijuana (45.5\%), then are the cities of Agua Prieta (45.0\%), Nogales (42.0\%), Mexicali (37.8 \%), Hermosillo (33\%), Ciudad Obregón (30.1\%), Ensenada (29.3\%) and San Luis Rio Colorado (32.1\%). This represents that in the border cities of Sonora and Baja California, are a lot industrial plants installed in this region.

\subsection{Evaluation of Contamination vs. Growth of Industrial Plants Installed}

The industrialization of large cities, leads the advance in the technologies in activities, taking place in the industrial 
plants of cities [10]. Regions with a greater amount of traffic, work and social stress, was increased very fast the generation of waste and emissions to the air, being a important aspect of deterioration the atmosphere and causing imbalance in the environment, which can be a factor in the climate change [11]. Due to both professional development opportunities, technical and labor required, the migrating populations of small cities and towns to big cities, sometimes causing serious consequences for the unconsciousness of environmental care. Water pollution is discharged because solid and liquid waste nitrates, sulfides and chlorides mainly, on the surface aquifers and groundwater, rivers, lakes, waterways and sometimes reach the great seas and oceans, changing characteristics of marine life [12]. Air pollution problems, are industrial emissions, vehicle and gas evolution of solid waste in water and soil, being mainly nitrates, sulfides, chlorides and dust. The contamination in soil is also very detrimental, because not only deteriorates the surface, but some may flow to waste where the water flows into the ground or underground.

\subsection{Sources of Emission}

Most of the emissions of pollutants from water, air and soil are anthropogenic, resulting from the deterioration of the environment to the generation and spread of diseases mainly respiratory rate, heart, stomach and intestinal [13]. The natural emission sources such as erosion, drought, frost and even earthquakes are a consequence of anthropogenic activities. This contributes to the decline of the family economy and regions, being necessary the medical care and low yield in the industrial operations. Another factor to take into account is the pollution in the indoor of industrial plants, are the generation of infections very easily [14].

\section{Methodology}

This study was carrying out in the cities mentioned above, where were developed industrial activities and near of it, that are explained below with the characteristics that are mentioned now:

1. Percentage increase of companies in Sonora and Baja California.

2. A survey was conducted from 2007 to 2009 to 100 people in each city analyzed to know the main waste and emissions from industrial, domestic and commercial activities.

3. Assessing the quality of water, air and soil monitoring with specialized techniques, measuring the $\mathrm{pH}$ in water and moist soil, to know the acidity of water used in domestic, industrial and irrigation and fertile land use or recovery of these. For air quality monitored in indoor of industrial plants, were used the Sulfation Plates Technique (SPT) [15] and the Wet Candle Method (WCM) [16]. In the case of soil $\mathrm{pH}$ analyzes were performed in order to know whether the level of acidity and know if are fertile for agricultural or other use of importance. The monitoring techniques and methods are shown in Table 2. Sections marked with dark markings, indicate the equipment, techniques and methods used in each section, representing in border cities: Agua Prieta, Hermosillo, Nogales, Mexicali and Tijuana, the application of the four monitoring systems and the two techniques mentioned ( SPT and WCM) and in the cities of Ciudad Obregon, San Luis Rio Colorado and Ensenada, the last two monitoring systems.

Table 2. Monitoring of climatic and environmental factors in Sonora and Baja California

\begin{tabular}{|c|c|c|c|c|}
\hline $\begin{array}{c}\text { STATE } \\
\text { CITY }\end{array}$ & EMS & MMS & SPT & WCM \\
\hline $\begin{array}{l}\text { SONORA } \\
\text { Agua Prieta (AG) } \\
\text { Cd. Obregón (CO) } \\
\text { Hermosillo (HER) } \\
\text { Nogales (NOG) } \\
\text { San Luis R.C. } \\
\text { (SLRC) }\end{array}$ & & & & \\
\hline $\begin{array}{l}\text { BAJA } \\
\text { CALIFORNIA } \\
\text { Ensenada (ENS) } \\
\text { Mexicali (MEX) } \\
\text { Tijuana (TIJ) }\end{array}$ & & & & \\
\hline
\end{tabular}

EMS. Environmental Monitoring System, MMS. Meteorological Monitoring System

In cities where there are EMS and MMS, was contemplated for this section, the evaluation of climatic and environmental factors. In cities where they do not have the EMS and MMS, was used portable monitors to measure pollution of water, air and soil temperature, relative humidity and solar radiation.

\section{Results}

The analysis of the relationship of increased industrial plants in Sonora-Baja California region, indicate that are uncontrolled growth of it in the large cities, causing a drastic climate change with variations in the each regional weather. This is consistent with other studies conducted in different parts of the world. The results are shown from the sections of the methodology, as follows:

1. Analysis of the percentage increase. This was made to determine the increase of the industrial plants and the deterioration of the regions around it.

2. Assessment surveys, An arising from the 10 questions assessed the four most important was made. The values indicate percentages in each city, for a better understanding of the views of the public (Table 3). 3. Analysis of pollution in water, air and soil. This shows the concentration levels of pollutants that react with the surface and the atmosphere inside and outside. Below are the results separately in water, air and soil. 
a) Water analysis. An evaluation of $\mathrm{pH}$ in underground aquifers, lakes, rivers and waterways was made. Table 4 shows the average $\mathrm{pH}$ levels in surface water of the cities evaluated, indicating that in the nearest locations to industrial plants are most affected.

As seen in the table 4, a representation of it, shows the $\mathrm{pH}$ levels in each region and in different environments evaluated aquifers, indicating that the percentage increases in border has a greater increase $(\%) \mathrm{pH}$ levels, showing that may be another factor not considered in this study which is essential for climate change in surface aquifers and groundwater.

b) Air Pollution. Information of analysis of the data of EMS, MMS, PTS and WCM carry out. This section explains how increased concentration levels of air pollutants in the different cities where the study was conducted (Table 5).

The levels of concentration of air pollutants, was measured according to the international environmental agreements environmental authorities of Mexico (SEMARNAT, Secretary of Environment and Natural
Resources) and the U.S. (EPA, Environmental Protection Agency). The table 5, shows the percentage of increases for the pollutants evaluated, being monitored by specialized equipments, techniques and methods. This indicates the low level of awareness of environmental care, which causes drastic changes in the environmental and climatic factors and thus in the climate change in each region, considering that these variations may have been factors in some natural disasters in this region northwest the country.

c) Soil. An analysis of $\mathrm{pH}$ in soil near industrial plants was made. The development is the same process as in surface aquifers and groundwater, but in this section shows the results of the soil. Measurements carry out on land near of the industrial plants, at four distances to the round: 100, 250, 500 and 1000 meters. The evaluation showed in Table 6 , indicates $\mathrm{pH}$ levels near industrial plants in each region, with the cities which presents a greater degree of deterioration in the border areas, representing that there may be another factor not considered in the investigation, as mentioned above, a key element in climate change in this region.

Table 3. Analysis of interviews of people in cities of Sonora and Baja California (2007-2009)

\begin{tabular}{|c|c|c|c|c|c|c|c|c|c|c|c|c|c|c|c|}
\hline \multirow{2}{*}{$\begin{array}{c}\text { STATE } \\
\text { CITY }\end{array}$} & \multicolumn{2}{|c|}{$1 * *$} & \multicolumn{2}{|c|}{$2 * *$} & \multicolumn{6}{|c|}{$3 * *$} & \multicolumn{5}{|c|}{$4 * *$} \\
\hline & $\mathbf{B}$ & $\mathbf{P}$ & $\mathbf{Y}$ & $\mathbf{N}$ & $\mathbf{M}$ & $\mathbf{W}$ & $\mathbf{P F}$ & $\mathbf{P a}$ & $\mathbf{G}$ & $\mathbf{A A}$ & $\mathbf{E E}$ & MA & $\mathbf{M}$ & $\mathbf{P}$ & $\mathbf{A}$ \\
\hline \multicolumn{16}{|l|}{ SONORA } \\
\hline Agua Prieta (AG) & 48 & 52 & 88 & 12 & 21 & 16 & 17 & 13 & 17 & 16 & 23 & 21 & 16 & 20 & 20 \\
\hline Cd. Obregón (CO) & 39 & 61 & 82 & 18 & 22 & 13 & 14 & 18 & 15 & 18 & 26 & 18 & 19 & 21 & 16 \\
\hline Hermosillo (HER) & 45 & 55 & 80 & 20 & 20 & 19 & 15 & 21 & 14 & 11 & 25 & 17 & 22 & 17 & 19 \\
\hline Nogales (NOG) & 52 & 48 & 85 & 15 & 22 & 19 & 17 & 14 & 12 & 16 & 29 & 21 & 16 & 14 & 20 \\
\hline San Luis R.C. (SLRC) & 51 & 49 & 87 & 13 & 20 & 18 & 15 & 17 & 13 & 17 & 27 & 23 & 21 & 15 & 14 \\
\hline \multicolumn{16}{|l|}{ BAJA CALIFORNIA } \\
\hline Ensenada (ENS) & 47 & 53 & 87 & 13 & 19 & 19 & 16 & 17 & 14 & 15 & 28 & 23 & 20 & 16 & 13 \\
\hline Mexicali (MEX) & 51 & 49 & 88 & 12 & 22 & 17 & 13 & 16 & 15 & 17 & 24 & 21 & 18 & 19 & 18 \\
\hline Tijuana (TIJ) & 56 & 44 & 91 & 9 & 23 & 14 & 11 & 15 & 18 & 19 & 26 & 24 & 21 & 18 & 11 \\
\hline
\end{tabular}

$1 * *$ Do you think that the presence of industrial plants in the city is of benefit or detriment to the community?. Benefit (B) _ Prejudice (P)

$2 * *$ Do you considers that the increase of industrial plants in your city generates a weather climate?. $\mathrm{Y}$ _ $\mathrm{N}_{\text {_ }}$. $3 * *$ In the following activities, in which create major growth?. Metal $(\mathrm{M}), \ldots$ Wood $(\mathrm{W}) \ldots$ _, Plastic / Foam (PF) _ , Paper $(\mathrm{Pa}) \ldots$ , Agricultural Activities (AA)

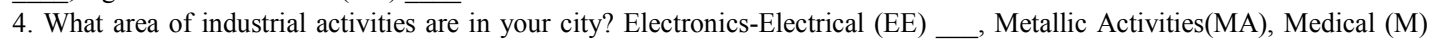
Paper Industries $(\mathrm{P})$ , Agricultural (A)

Table 4. $p$ H levels in regions with water in cities of Sonora and Baja California (2007-2009)

\begin{tabular}{|c|c|c|c|c|c|c|c|c|c|c|c|c|}
\hline \multirow{2}{*}{$\begin{array}{c}\text { STATE } \\
\text { CITY }\end{array}$} & \multicolumn{4}{|c|}{ pH (2007) } & \multicolumn{4}{|c|}{ pH (2009) } & \multicolumn{4}{|c|}{ INCREASE (\%) } \\
\hline & UGA & LA & $\mathbf{R}$ & SWF & UGA & LA & $\mathbf{R}$ & SWF & UGA & LA & $\mathbf{R}$ & SWF \\
\hline \multicolumn{13}{|l|}{ SONORA } \\
\hline Agua Prieta (AG) & 6.8 & 6.5 & 6.3 & 6.6 & 6.2 & 5.8 & 5.9 & 5.4 & 8.9 & 10.8 & 6.3 & 18.2 \\
\hline Cd. Obregón (CO) & 6.2 & 6.9 & 6.4 & 6.2 & 5.7 & 6.2 & 5.7 & 5.5 & 8.1 & 10.1 & 11.0 & 11.3 \\
\hline Hermosillo (HER) & 6.7 & 6.2 & 6.0 & 6.4 & 5.9 & 5.6 & 5.3 & 5.3 & 12.0 & 9.7 & 11.7 & 17.2 \\
\hline Nogales (NOG) & 7.1 & 6.8 & 6.3 & 6.3 & 5.4 & 5.1 & 5.6 & 5.2 & 24.0 & 28.2 & 11.1 & 17.5 \\
\hline San Luis R.C. (SLRC) & 6.8 & 6.5 & 6.8 & 6.1 & 4.9 & 5.3 & 5.1 & 4.8 & 28.0 & 22.1 & 28.0 & 21.3 \\
\hline
\end{tabular}




\begin{tabular}{|c|c|c|c|c|c|c|c|c|c|c|c|c|}
\hline Ensenada (ENS) & 6.4 & 6.7 & 6.6 & 6.3 & 5.3 & 5.7 & 5.2 & 5.6 & 17.2 & 15.0 & 21.2 & 11.1 \\
\hline Mexicali (MEX) & 6.6 & 6.9 & 6.8 & 6.2 & 4.4 & 5.3 & 5.5 & 5.4 & 33.3 & 23.2 & 20.3 & 12.9 \\
\hline Tijuana (TIJ) & 6.7 & 6.9 & 6.5 & 6.8 & 4.9 & 5.5 & 5.8 & 5.6 & 26.9 & 20.3 & 16.0 & 17.6 \\
\hline
\end{tabular}

UGA. Underground aquifers (3 meters), LA. Lakes, R. Rivers, SWF. Small water flows

Table 5. Air pollution level in cities of Sonora and Baja California (2007-2009)

\begin{tabular}{|c|c|c|c|c|c|c|c|c|c|}
\hline \multirow{2}{*}{$\begin{array}{l}\text { STATE } \\
\text { CITY }\end{array}$} & \multicolumn{4}{|c|}{ EMS $^{1}$} & \multicolumn{3}{|c|}{ MMS $^{2}$} & \multirow[t]{2}{*}{$\mathrm{PST}^{3}$} & \multirow[t]{2}{*}{$\mathrm{WCM}^{4}$} \\
\hline & $\mathrm{CO}$ & $\mathbf{N O}_{\mathbf{X}}$ & $\mathbf{O}_{3}$ & $\mathbf{S O}_{\mathbf{X}}$ & HR & RS & $\mathbf{T}$ & & \\
\hline \multirow{3}{*}{$\begin{array}{l}\text { SONORA } \\
\text { Agua Prieta (AG) }\end{array}$} & & & & & & & & & \\
\hline & $2^{\mathrm{a}} 3^{\mathrm{b}}$ & 2 & 2 & 2 & 2 & 2 & 2 & 2 & 2 \\
\hline & & 3 & 3 & 3 & 3 & 3 & 3 & 3 & 3 \\
\hline \multirow[t]{2}{*}{ Cd. Obregón (CO) } & & & & & 2 & 2 & 2 & 2 & 2 \\
\hline & & & & & 3 & 3 & 3 & 3 & 3 \\
\hline \multirow[t]{2}{*}{ Hermosillo (HER) } & & & & & 2 & 2 & 2 & 2 & 2 \\
\hline & & & & & 3 & 3 & 3 & 3 & 3 \\
\hline \multirow[t]{2}{*}{ Nogales (NOG) } & $2^{a} 3^{b}$ & 2 & 2 & 2 & 2 & 2 & 2 & 2 & 2 \\
\hline & & 3 & 3 & 3 & 3 & 3 & 3 & 3 & 3 \\
\hline \multirow{2}{*}{ San Luis R.C. (SLRC) } & & & & & 2 & 2 & 2 & 2 & 2 \\
\hline & & & & & 3 & 3 & 3 & 3 & 3 \\
\hline \multicolumn{10}{|l|}{ BAJA CALIFORNIA } \\
\hline \multirow[t]{2}{*}{ Ensenada (ENS) } & & & & & 3 & 3 & 3 & 3 & 3 \\
\hline & & & & & 4 & 4 & 4 & 4 & 4 \\
\hline \multirow[t]{2}{*}{ Mexicali (MEX) } & $3^{a}$ & 3 & 3 & 3 & 3 & 3 & 3 & 3 & 3 \\
\hline & $4^{\mathrm{b}}$ & 4 & 4 & 4 & 4 & 4 & 4 & 4 & 4 \\
\hline \multirow{2}{*}{ Tijuana (TIJ) } & $3^{a}$ & 3 & 3 & 3 & 3 & 3 & 3 & 3 & 3 \\
\hline & $4^{\mathrm{b}}$ & 4 & 4 & 4 & 4 & 4 & 4 & 4 & 4 \\
\hline
\end{tabular}

${ }^{1}$ Seasonal percentage increases of levels of concentration of air pollution at week from 2005 to 2009 according to the information of EMS (a and b for winter to summer).

${ }^{2}$ Climatic factors: relative humidity $(\mathrm{RH}, \%)$, solar radiation (RS, $\left.\mathrm{W} / \mathrm{m} 2\right)$ and Temperature $\left({ }^{\circ} \mathrm{C}\right)$.

${ }^{3}$ Levels of sulfurs in indoor of industrial plants monitored by the PST.

${ }^{4}$ Levels of chlorides in indoor of industrial plants monitored by the WCM (in marine zones).

$1=$ No health problem, $2=$ Bit health problems, $3=$ Considered health problems, $4=$ Hard health problems).

Table 6. $p H$ levels in soil near of the industrial plants of Sonora and Baja California (2007-2009)

\begin{tabular}{|c|c|c|c|c|c|c|c|c|c|c|c|c|}
\hline \multirow{2}{*}{$\begin{array}{c}\text { STATE } \\
\text { CITY }\end{array}$} & \multicolumn{4}{|c|}{ pH (2007) } & \multicolumn{4}{|c|}{ pH (2009) } & \multicolumn{4}{|c|}{ INCREMENTO (\%) } \\
\hline & $100^{\mathrm{a}}$ & 250 & 500 & 1000 & $100^{\mathrm{a}}$ & 250 & 500 & 1000 & $100^{\mathrm{a}}$ & 250 & 500 & 1000 \\
\hline \multicolumn{13}{|l|}{$\overline{\text { SONORA }}$} \\
\hline Agua Prieta (AG) & 5.2 & 5.4 & 6.1 & 6.8 & 4.9 & 5.2 & 5.6 & 6.2 & 5.8 & 3.7 & 8.2 & 8.8 \\
\hline Cd. Obregón (CO) & 5.8 & 5.7 & 6.4 & 6.9 & 5.5 & 5.4 & 5.8 & 6.3 & 5.2 & 5.3 & 9.4 & 8.7 \\
\hline Hermosillo (HER) & 5.9 & 5.7 & 6.3 & 7.1 & 5.7 & 5.3 & 5.7 & 6.5 & 3.4 & 7.1 & 9.5 & 8.5 \\
\hline Nogales (NOG) & 5.6 & 5.6 & 6.4 & 6.6 & 5.5 & 5.2 & 5.9 & 6.0 & 1.8 & 7.1 & 7.8 & 9.1 \\
\hline San Luis R.C. (SLRC) & 5.4 & 5.3 & 6.6 & 6.8 & 4.9 & 4.8 & 6.1 & 6.2 & 9.3 & 9.4 & 7.8 & 8.8 \\
\hline \multicolumn{13}{|l|}{ BAJA CALIFORNIA } \\
\hline Ensenada (ENS) & 5.4 & 5.6 & 5.9 & 6.4 & 5.1 & 5.3 & 5.7 & 6.1 & 5.6 & 5.4 & 3.4 & 4.7 \\
\hline Mexicali (MEX) & 5.1 & 5.4 & 6.0 & 6.5 & 4.7 & 5.1 & 5.7 & 6.0 & 7.8 & 5.6 & 5.0 & 7.7 \\
\hline Tijuana (TIJ) & 5.3 & 5.5 & 6.1 & 6.4 & 5.0 & 5.0 & 5.6 & 5.6 & 5.7 & 9.1 & 8.2 & 8.2 \\
\hline
\end{tabular}

${ }^{\mathrm{a}}$ Distance in meter radius away from the soil $\mathrm{pH}$ measurements in the industrial plants.

\section{Conclusions}

The lack of control of solid and liquid wastes from industrial plants, and in domestic and commercial activities are important elements in the climate change, that every day feel its consequences with natural disasters such as drought, frost, earthquakes and drastic changes of climatic and environmental damage our environment. There have been a wide variety of environmental impact studies with significant results that support the lack of awareness of environmental care and will generate an important source of sustainability of human life, animals and plants. Still, they continue to have problems with this analysis environment and informs the community and government authorities and other sectors, it is necessary to consider care for our environment, and prevent some types of natural disasters that are the cause of great human and economic losses. This research was made in the cities of Sonora and Baja California States, where are presented highest problems of pollution, principally in the cities of Baja California and less in Sonora, with major levels that exceed the standards of air quality than other cities of the country. The study is in progress to find other factors that create climate change in each region evaluated and serve as a 
model for other areas of the Mexican Republic.

\section{References}

[1] López B. G., "Caracterización de la corrosión en materiales metálicos de la industria electrónica en Mexicali, Tesis Doctoral, 2008".

[2] Gutiérrez A., Torres F. \& Urbina R.; El cambio climático; causas y consecuencias, Editorial Oceánica, 2000.

[3] George J. \& Frankental P; Impact of climate change and their effect in agricultural activities; Editorial Mc Graw Hill, 2002.

[4] Smith R., Thomas A. \& Murray E.; The climate change and the food chain; Editorial Mc Graw Hill, 2004.

[5] Ubaldo H. \& Rosas D.; Desastres naturales por cambio climático; Editorial Panamericana; 1999.

[6] Fernández T., Morales A. \& Reynolds W.; Desequilibrio social en las grandes urbes; Editorial Oceánica, 2000.

[7] G. López, H. Tiznado, G. Soto, W. De la Cruz, B. Valdez M. Schorr, R. Zlatev, "Corrosión de dispositivos electrónicos por contaminantes atmosférica en interiores de plantas industriales de ambientes áridos y marinos", Nova Scientia, ISSN 2007-0705, 2010, (en prensa).

[8] Asociación de Maquiladoras locales: Agua Prieta,
Hermosillo, Nogales en Sonora y Mexicali y Tijuana en Baja California.

[9] CANACINTRA in local comunidades: Cd. Obregon, San Luis Rio Colorado en Sonora y Ensenada en Baja California.

[10] Betis H. \& Robuski M.; High technology applied to industrial systems; Editorial Mc Grwa Hill, 2002.

[11] B.G. Lopez, S.B. Valdez, K.R. Zlatev, P.J. Flores, B.M. Carrillo and W.M. Schorr, "Corrosion of metals at indoor conditions in the electronics manufacturing industry", AntiCorrosion Methods and Materials, ISSN 0003-5599,54/6 (2007) 354-359, 2007.

[12] González R. \& Pedroza M.; Impactos ambientales; una visión del cambio climático; Editorial Trillas, 2003.

[13] Rogers G. \& Zackosky A.; Industrial technology in the big cities and climate change; Editorial Mc Graw Hill; 2005.

[14] López Gustavo, Valdez Benjamin, Schorr Miguel, Rosas Navor, Tiznado Hugo, Soto Gerardo, (2010) "Influence of climate factors on copper corrosion in electronic equipment and devices", Anti-Corrosion Methods and Materials, Vol. 57, pp. $148-152,2010$.

[15] ASTM G91 - 97(2004) Standard Practice for Monitoring Atmospheric SO2 Using the Sulfation Plate Technique.

[16] ASTM G140 - 02(2008) Standard Test Method for Determining Atmospheric Chloride Deposition Rate by Wet Candle Method. 